\section{Conflict of interest and funding: None declared.}

\section{References}

1. Department of Medical Education and Research, Government of Haryana. Notification (No. 16/17/2019-6HBIV dated 6th November 2020 [cited 2020 Nov 12]. Available from: http://dmerharyana.org/ wp-content/uploads/2020/11/Policy.pdf

2. National Medical Commission. List of Colleges teaching MBBS in India. Date unknown [cited 2020 Nov 12]. Available from: https:// www.nmc.org.in/information-desk/for-students-to-study-in-india/ list-of-college-teaching-mbbs

3. Ministry of Health and Family Welfare, Govt of India. Rural Health Statistics 2018-19[cited 2020 Nov 12]. pp 158 and 168. Available from:https://main.mohfw.gov.in/sites/default/files/ Final\%20RHS\%202018-19_0.pdf
4. Sharma DC. India still struggles with rural doctor shortages. Lancet 2015 Dec 12; 386 (10011): 2381-2. Doi: 10.1016/S0140 6736(15)01231-3.

5. Shroff ZC, Murthy S, Rao KD. Attracting doctors to rural areas: A case study of the post-graduate seat reservation scheme in Andhra Pradesh. Indian J Community Med. 2013 Jan; 38(1):27-32. Doi: 10.4103/0970-0218.106624

6. Deshpande SR. Rural and urban health training centres of medical colleges in India: A prescription for their revamp. Natl Med J India. 2015 May-Jun; 28(3):141-3.

7. Observations and Interviews conducted by the author during 2018 19 for his doctoral thesis titled 'Understanding of Primary Health Care among Faculty of Community Medicine in India: A Study of Knowledge, Perceptions and Pedagogy, under the supervision of Prof. Ritu Priya (Jawaharlal Nehru University, New Delhi).

\title{
The Spiral
}

\section{RAKHI GHOSHAL}

Episodes of domestic violence are incredibly more common than what is documented. While we have had a law against it in India since 2005, the prevalence of domestic violence is high in India at close to 30 percent (as per National Family Health Survey, 2015-16). Yet, with interventions such as Dilaasa in Maharashtra, Bhoomika in Kerala, and Sukoon in Haryana - among others visibility has increased; and so has support seeking behaviour. The narrative here is based on my personal observation - with some extensions from my imagination built in to give a structure to the narrative - which jarred as I saw how the consequences of violence can be so debilitating, how violence begets more violence ${ }^{*}$, becomes a question of contingent power; how it flows on through the survivor, creating more survivors.

She walked out the day he hit her with a hot ladle. Dragging her wailing four-year-old along and holding an oil stained cloth duster to a bleeding forehead, she left the one-room tenement that had been her address these past six years, as soon as her husband went up to the terrace for his evening smoke; a neighbour called out after her, surprised, but she rushed past him. Time is surely short when one is running away.

\section{$* * * * *$}

Author: Rakhi Ghoshal (rakhi.ghoshal@gmail.com), Project Manager, 'Health Systems Response to Gender Based Violence' CARE India, Patna, Bihar, INDIA.

To cite: Ghoshal R. The Spiral. Indian J Med Ethics. 2021 Oct-Dec; 6(4) NS: 328 30. DOI: 10.20529/IJME.2021.032.

Published online on May 1, 2021.

Manuscript Editor: Olinda Timms

(c) Indian Journal of Medical Ethics 2021
I met Shabnam, a 25-year-old driven-up-the-wall woman at a crisis counselling centre at a public hospital in Mumbai. She had come with her aunt, who waited outside, barely managing to keep up with the skinny, hyperactive four-year-old boy she was baby-sitting ever since Shabnam had taken shelter at her house. Shabnam was dry eyed, tears had fossilised long since and now her eyes burnt like embers. The scar left behind by the gash was just over a month old. Shabnam shared with the counsellor how the beatings had increased over the past six months; she said she did not want to go back to that house, and at the same time she knew she could not stay with her aunt for long; her uncle was ill and there were serious space issues in the house. Shabnam did not know where to go.

Shabnam had had a job till she moved to her aunt's house, and it was the job that had been the root of the everescalating arguments; her husband suspected her of infidelity at the workplace and insisted that she give up the job. She used to work as a saleswoman at a big departmental store, on a 10-hour shift, six days a week, earning 12 thousand a month. Once she moved to her aunt's house, she was too far away from her workplace to make it on time every day. Also, she could not leave her son to be taken care of by the elderly lady alone. The boy had not been going to school ever since she had moved out. Shabnam was angry that her husband had finally succeeded in making her give up her job. The fossilised anger glowed in the tips of her fingernails, the edges of which she bit off from time to time. I watched her in silence, I was observing the counselling session - a social science fly on the wall.

Shabnam started off easily, very unlike the other survivors who took a lot of prodding to open up; she told us of the slaps 
and the punches, the accusations and the abuses. The verbal abuses had been increasing over the past few months, the slaps had then begun. The slaps became more and more frequent and provoked by less and less, even as she kept hoping that the violence would stagnate someday, if not stop.

When Shabnam paused, the counsellor asked if the husband had had a problem with her job from the very start; "No", Shabnam clarified, the problems began only after he lost his job and began staying at home. Before that, when they both worked, he was a much better husband. That was about seven to eight months ago. After the beatings began, Shabnam did toy with the idea that she would give up the job; but with the changed circumstances, how could they then afford the rent, the school fees? She said that she had tried negotiating with her husband that once he got another job, she would give up hers and stay at home. But he did not act on that either.

The counsellor wanted to know if he abused her sexually as well. Shabnam responded that he had stopped having sex with her for more than six months now. Did he have any extramarital affair, she was asked; No, she was sure, he did not. In fact, he had stopped stepping out of the house almost, he hardly ever went out to meet his friends. "He used to be home the whole day! It would suffocate me. I would go mad on my off-days - he would be home and keep abusing me the whole day - if I asked him to go for a walk or go meet his friends, he would think I needed privacy to call up some boyfriend or the other, and would start abusing me. He would hit me on the smallest of pretexts."

The day he hit her with a hot ladle because he felt she had not folded his trousers properly, she left him. Shabnam set down the paper cup - the last dregs of the hospital tea, utterly syrupy, were drained off the cup. The counsellor offered her another cup which she coyly declined. We had covered close to three quarters of an hour now; from my seat, I could look through the half-open door - the hyperactive four-year-old had fallen asleep in his grandmother's arms. I wondered if he was hungry.

'How did your husband lose his job?' Shabnam said that he had worked as an office boy at some small private organisation; he used to earn 15 thousand a month. Around eight months ago, he had fallen ill with high fever and severe joint aches; he had not been able to get up from the bed for three days at a stretch. Finally, after a week, when he could, he went to work and half an hour after he had stepped into office, he was unceremoniously fired. The "boss madam" told him he was no more needed as he was not dependable, took leave without prior intimation, and so he would also have to forego his salary for the first few days of that month as penalty. "He was very much afraid of boss madam," Shabnam added, "he did not say anything to her; just walked out". That afternoon he got home and shut himself off from the world. The abuse, cynicism, suspicion, and the beatings actually began then.

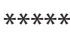

The counsellor was writing into a form, asking some further questions. My mind wandered to Shabnam's life at her aunt's house, back to her husband's office ... a three or four bedroomed rented apartment, on some obscure floor, up some semi-residential building, now converted into an office space, cheap ply boards roleplaying as walls, overlooking some other equally nondescript building, or maybe the chaotic arteries of the city below. This city was a human being, it grew taller with each passing decade, people stayed further and further up in the air, balconies were co-opted into rooms, toilets so cramped that they were ready to implode, walls thin, space at an unimaginable premium.

Some small private organisation, running on low salaries, no social security, no accountability; an office boy, a month before Diwali, falls ill, takes leave when none has been allotted. Nobody asks him why he had to take the leave, nobody enquires after his health, nobody is worried about how he will take care of the family - there are no unions, no policies, no understanding (or willingness) to seek legal redress for the sudden termination. The boss madam knows no questions will be asked by the office boy; additionally, no Diwali bonus would have to be paid to him; too many potential office boys were available in this vertical city which thrived on the collective dreams of the migrants of India; this office boy would vanish into the crowd at the foot of the building, he would be lost forever. It hardly mattered to the boss madam - she had shown him his rightful place, besides setting a strong example to future transgressors and leavetakers. Way too many birds had been killed with one stone.

She would never know of Shabnam and the beatings, the exoffice boy self-confined to the house, the humiliation and helpless anger that had been buried deep within him, the thoroughly hidden pleas for help.

$* * * * *$

Shabnam walked out of the door; her son had woken up by now. Since morning, he had been waiting in the lobby for close to four hours now. Shabnam looked exhausted, reliving the pain can be both therapeutic and agonising, all at once, one feeling bleeding into the other. I looked at the crowded ward outside; lunchtime had come and gone. The boy began whimpering on seeing his mother. He tugged at her salwar while she tried to put her papers back in her bag - she wagged a finger at him, said something, evidently asking him to keep quiet. When the boy tugged at her again, she turned around and slapped him, across the cheeks, once, twice, thrice.

Harder each time. 
*Note:

Domestic abuse has multiple health consequences, several chronic and long-term ones. It also has intergenerational effects, ie, it affects the next generation. A woman who undergoes violence when pregnant, has a higher chance of miscarriage, stillbirth and other foetal health consequences. Children who grow up in households where domestic violence is a norm, have much higher likelihood of dropping out of school, mental and emotional development challenges. In National Family Health Survey (NFHS) of India (2015-16), data showed that for all women who said they were themselves suffering abuse at the hands of their husbands, 58 percent said they had grown up seeing their mothers getting beaten by their fathers. Violence commonly becomes normalised in such scenarios and even women start justifying it. In NFHS (2015-16), 52 percent women, compared to 42 percent men, justified wife-beating. The spiral of violence implicates generations.

\title{
The Liquid Miscreant
}

\author{
AISWARYA SASI
}

\section{Introduction}

Alcoholism is a social issue that cannot be undermined in today's setting. This work aims to plunge readers into the plight of the direct and indirect victims of alcohol abuse.

In the second year of medical college, I began my clinical postings. The posting that has had the biggest impact for me thus far was my psychiatry posting. In the course of just one week, I had lent my ears to myriad stories, each one more soul-stirring than its predecessor.

One Tuesday morning, the second day of our posting, I peeped into ward after ward, looking for a patient to speak to. The sole inhabitant of one of the wards was a plump little boy. Wrought with curiosity, I thought about taking his history, but dismissed the thought at once. He was only a little boy and I wasn't entirely sure how I would go about talking to him. Just as I made my way to the next ward, a cheery voice called out, "Doctor!" I peeped into the ward again, and the boy beckoned to me. His grandmother was sitting with him on the bed and chided, "Don't trouble akka, she must be busy!" The little boy smiled. "He was just bored. Sorry for disturbing you," she said to me."No that's alright," I

Author: Aiswarya Sasi (aiswarya.s@stjohns.in), Medical Intern, St John's Medical College Hospital, Koramangala, Bengaluru, 560034 INDIA.

To cite: Sasi A. The Liquid Miscreant. Indian J Med Ethics. 2021 Oct-Dec; 6(4) NS: 330-31. DOI: 10.20529/IJME.2021.033.

Published online on May 1, 2021.

Manuscript Editor: Rakhi Ghoshal

(c) Indian Journal of Medical Ethics 2021 said. I almost told her that as medical students, we had nothing to be busy with in the wards, and that I was glad to finally have something to do; instead, I just smiled at the two of them.

"What's your name?" I asked him. "My name is Mahesh," he said brightly. He chattered on happily for some time about nothing in particular. As soon as his mother entered the room, in a fraction of a second, his demeanour was transformed. The smile was now replaced by a frown and he stopped talking. His mother sat down. I introduced myself to his mother and asked her why he had been brought to the hospital. "He's a nuisance," she said expressionlessly. "He disturbs the class, doesn't study and doesn't let anybody else study. His marks are pathetic and he's quite useless. The doctors have diagnosed him with Attention Deficit Hyperactivity Disorder." Mahesh was quiet, obviously listening to his mother's words. "It's such a pain for me. I have to come here before going to work to bring his food and it's so far away." She sounded exhausted. She went on to scold him for something, in response to which he called her a 'dummi', or a 'fat person'. His mother left in the next few minutes. The moment she left, he was lively and cheerful again.

"He doesn't get along with his mother," his grandmother explained. "Mahesh, you shouldn't call your mother a dummi, that's not a good habit," I said to him. "I don't like her," he said curtly. "Can I talk to him outside for a while?" I asked his grandmother and she obliged without a second thought. As we walked out of the ward, I asked him why he didn't like his mother. "She is always saying bad things about me. After my father comes home and beats her, she becomes sad and she cries and if I ask her anything, she beats me. She makes me eat dinner very early - at $6 \mathrm{pm}$, and she makes me eat really fast, before my father gets home. If I ask for more, or if I tell her I'm 